\title{
Meteorological Drought Assessment in Wonogiri District
}

\author{
Karlina \\ Graduate School of Engineering, Kyoto University, Japan \\ karlina.sipil@gmail.com
}

\begin{abstract}
Drought is one of natural disaster occurrences that affect many life aspects such as agricultural and economy. Drought is one of hazard that affected by extreme condition due to climate change. Wonogiri is one of districts in Indonesia that has a high risk of meteorological drought. This area tends to have less rainfall than other areas that make the condition drier. This study is aimed to provide some information required in determining the drought disaster mitigation through analysis of the drought characteristics, for both historical and future condition. For the historical condition analysis, the input is 12 years of daily rainfall recorded data from 1990 to 2001 in 15 rain gauges. In case of the future assessment, the meteorological drought was analyzed by using Effective Drought Index (EDI) and Standardized Precipitation Index (SPI) methods. Input data for the future assessment is 90 years of daily rainfall which was generated by using climate model HadCM3 scenario A2 and B2. The future data prediction was done by using Automated Statistical Downscaling software. Statistical criteria i.e. Root Mean Square Error (RMSE), regression coefficient and standard deviation were used for testing the model accuracy. The drought coefficient obtained from the analysis using EDI and SPI then was applied to draw drought risk map using GIS software in Wonogiri District for historical and future condition. The results show that for the historical condition, the most severe drought occurred in 1997-1998. This extreme condition related to ENSO phenomenon that happened in this area. Compared with the historical condition, the number of future drought event in 2080 period is less than the historical one. This result agree with the rainfall prediction. The generated rainfall for both scenarios are increase from existing period to 2080's.
\end{abstract}

Keywords: meteorological drought, climate change, rainfall, drought map

\section{INTRODUCTION}

Among many types of disaster in Indonesia, drought has become more common recently. This phenomenon has been experienced by several islands in the country and is not yet clearly known whether affected by the issue of the global warming and/or climate change. This drought phenomenon also took place in the Wonogiri District, Island of Java, Indonesia.

Drought investigation and assessment could be conducted by using drought indexes such as Standardized Precipitation Index (SPI) (McKee, et al., 1993) and Effective Drought Index (EDI) (Byun \& Wilhite, 1999). Both these methods use precipitation data as the input to the calculation.

Besides historical condition, the future condition assessment is also conducted to know the climate change effect on drought condition. This study uses Green House Gasses (GHG) emission scenario from Intergovernmental Panel on Climate Change (IPCC) and climate model from Hadley Centre to predict the future climate. The weather prediction is conducted by using Automated Statistical Downscaling (ASD) (Hessami, et al., 2007).
The aim of this study is to assess drought severity in Wonogiri District by using EDI and SPI methods. Besides, this study was conducted to gain accurate information on the drought potency and severity in the future condition in Wonogiri District based on climate prediction data using climate scenario and emission scenario by IPCC. Also, the drought mapping was used to define the spatial drought distribution in this area.

\section{DROUGHT ANALYSIS}

\subsection{Meteorological Drought}

Drought is a prolonged period where the moisture condition is abnormal and lower than the normal state in a given region (Heddinghaus \& Sabol, 1991). Besides that, (McKee, et al., 1993) mention that drought is a condition of the deficiency precipitation in a period of time. Some of the drought indexes that used to use on drought assessment are Standardized Precipitation Index (SPI) and Effective Drought Index (EDI).

\subsection{Standardized Precipitation Index}

McKee, et al. developed SPI index in 1993. The input data for the calculation is monthly precipitation data. 
The calculation of the SPI index in this study is conducted by using Standardized Precipitation Index Calculator program. The drought classification by SPI in this study is given in Table 1 (Lloyd-Hughes \& Saunders, 2002).

Table 1.Drought classification by SPI

\begin{tabular}{lll}
\hline $\begin{array}{l}\text { Drought } \\
\text { classification }\end{array}$ & Category & $\begin{array}{l}\text { Probability } \\
(\%)\end{array}$ \\
\hline $\mathrm{SPI} \geq 2.00$ & Extremely wet & 2.3 \\
$1.50 \leq \mathrm{SPI} \leq 1.99$ & Severely wet & 4.4 \\
$1.00 \leq \mathrm{SPI} \leq 1.49$ & Moderately wet & 9.2 \\
$0.00 \leq \mathrm{SPI} \leq 0.99$ & Mildly wet & 34.1 \\
$-0.99 \leq \mathrm{SPI} \leq 0$ & Mild drought & 34.1 \\
$-1.49 \leq \mathrm{SPI} \leq-1.00$ & Moderate drought & 9.2 \\
$-1.99 \leq \mathrm{SPI} \leq-1.5$ & Severe drought & 4.4 \\
$\mathrm{SPI} \leq-2.00$ & Extreme drought & 2.3 \\
\hline
\end{tabular}

\subsection{Effective Drought Index}

EDI was developed by Byun, et al., in 1999. Almost the same as SPI, EDI uses precipitation data as the input to the calculation. The drought classification by EDI is given by Table 2 .

Table 2.Drought classification using EDI

\begin{tabular}{ll}
\hline Drought classification & Category \\
\hline Extremely wet & EDI $\geq 2.00$ \\
Severely wet & $1.50 \leq \mathrm{EDI} \leq 1.99$ \\
Moderately wet & $1.00 \leq \mathrm{EDI} \leq 1.49$ \\
Mildly wet & $0.00 \leq \mathrm{EDI} \leq 0.99$ \\
Mild drought & $-1.0 \leq \mathrm{EDI}<0$ \\
Moderate drought & $-1.5 \leq \mathrm{EDI}<-1.0$ \\
Severe drought & $-2.0 \leq \mathrm{EDI}<-1.5$ \\
Extreme drought & $\mathrm{EDI}<-2.0$ \\
\hline
\end{tabular}

Drought calculation is conducted by using "Monthly EDI Program" that was developed by Prof. Byun, HiRyong, Department of Environment Atmospheric Sciences, Pukyong National University, Republic of Korea (Byun \& Wilhite, 1999).

\subsection{Climate Downscaling}

Future climate prediction technique that used to use is global data downscaling. Global data that is used is
HadCM3 climate model with A2 and B2 scenario. Downscaling is conducted to improve the data resolution so that could reflect the actual condition. Statistical downscaling was developed with the assumption that regional climate is affected by local climate. Based on this assumption, global climate has the same statistical variables as local climate, in the other words, the global climate could be used as input of the local climate variables downscaling process using observe meteorological data.

\section{RESEARCH METHOD}

This study is conducted in Wonogiri District, Central Java Province. Precipitation data that is used in this study is collected from 15 rain gauge stations with 12 years data from 1990 up to 2001. The rain gauge stations are Selogiri, Kepatihan, Manyaran, Wuryantoro, Wonogiri, Ngancar, Pracimantoro, Girimarto, Sidoharjo, Slogohimo, Jatisrono, Wd.Krisak, Nguntoronadi, Plumbon, and Kedungguling. Rain gauge stations spatial distribution is shown in Figure 1.

SPI calculation was conducted for 1, 3, 6, 12, and 24time scale by using Standardized Precipitation Index and for EDI calculation was carried out by using "Monthly EDI Program." The future climate prediction, especially future precipitation data prediction was performed by using reanalysis data from NCEP and climate model data from IPCC. The climate model that is used in this study is HadCM3. Greenhouse gasses emission that was used A2 andB2 scenario. Precipitation downscaling was conducted by using Automated Statistical Downscaling (ASD) software- (IPCC, 2000).

\section{ANALYSIS AND DISCUSSIONS}

\subsection{Historical Precipitation}

Monthly average rainfall data from fifteen stations show the same characteristic. The wet season happens from November to April and dry season happens from May to October. The peak of the dry season happens in September, and the other side the peak of the wet season is February. 


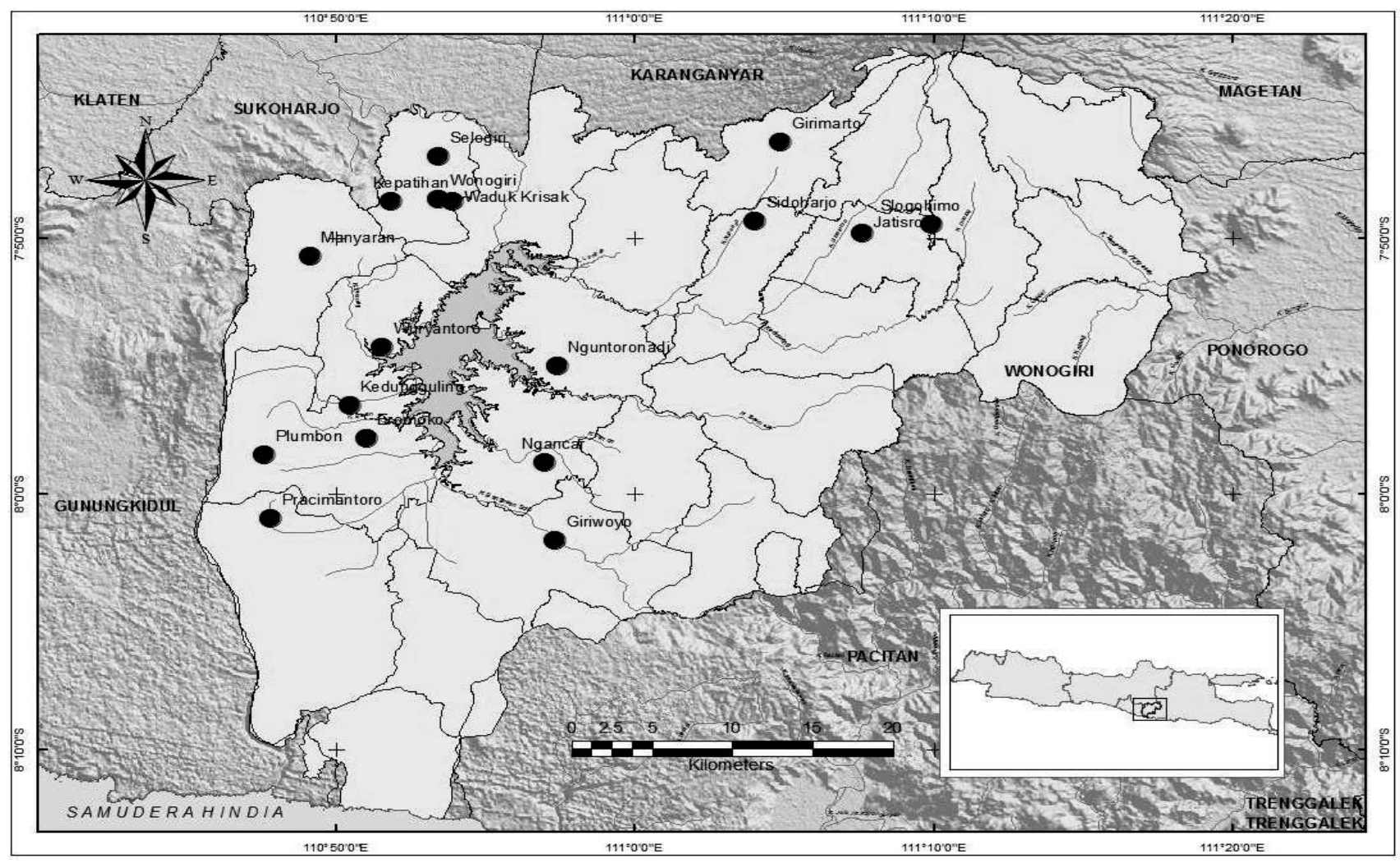

Figure 1.The spatial distribution of rain gauges station in the study area.

This rainfall pattern has the same characteristic with rainfall pattern in over Indonesia. The monthly rainfall pattern in Wonogiri District was shown in Figure 2. The lower annual precipitation in this area happened in 1997.

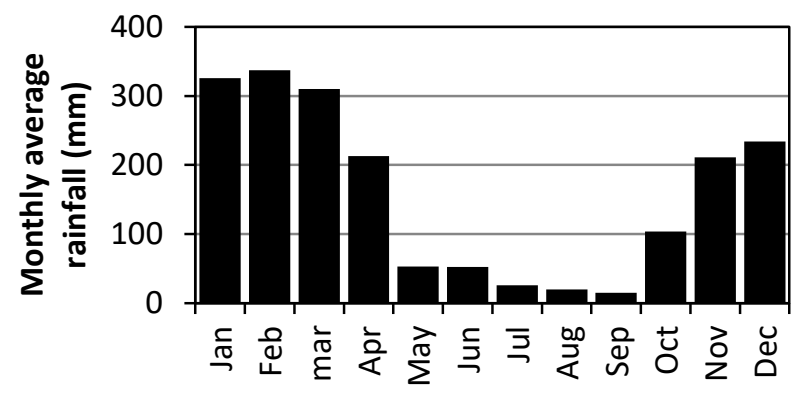

Figure 2. Monthly average rainfall from 1990 - 2001.

\subsection{Precipitation Downscaling}

\subsubsection{Historical Condition}

The result of the monthly precipitation downscaling tends to have less amount than the actual condition in wet periods and higher in dry periods. Monthly precipitation in this study area tends to less than the observed rainfall data as shown in Figure 3.
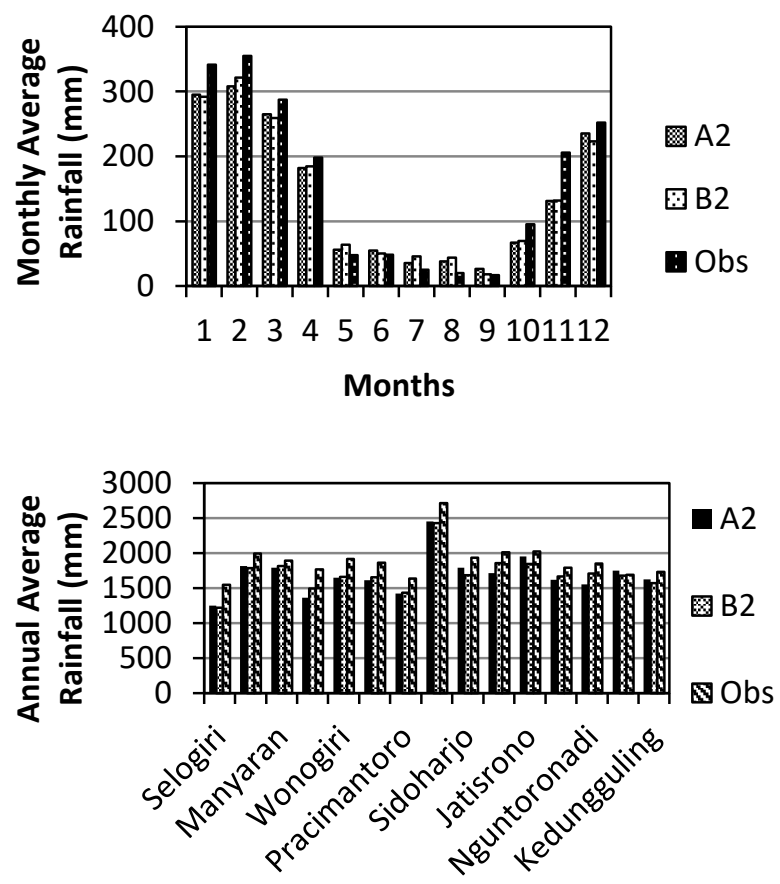

Figure 3. The differences between observed monthly and annual rainfall data (1990-2001) and HadCM3 climate model simulation for A2 and B2 scenarios.

\subsubsection{Future Precipitation}

Based on the result of the analysis, the changes of the precipitation amount from 2020's periods to 2050's 
periods are not significant for both scenarios. The significant changes happen for 2080's period as shown in Figure 4. The rise of the monthly future precipitation for A2 scenario is higher than B2 scenario in 2080's period.

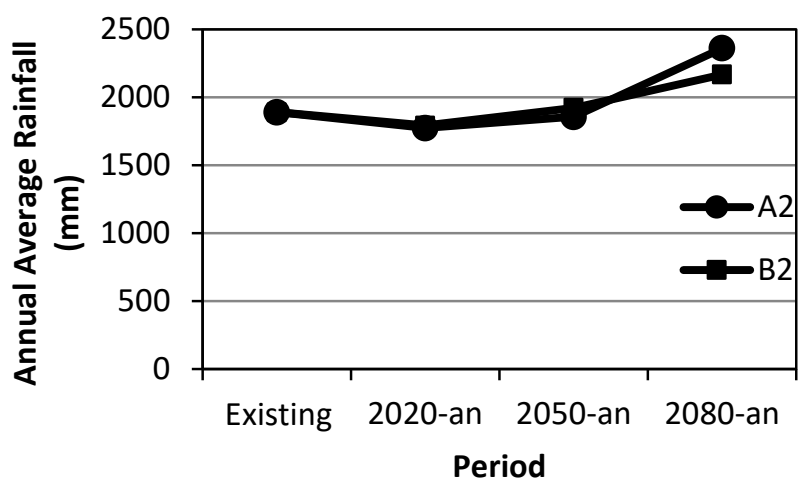

Figure 4.The changes of the annual precipitation in future condition.

\subsection{Historical Drought}

The result of the historical drought assessment using EDI and SPI-1, -3, -6, -12, -24-time scale is shown in Figure 5. Figure 5 indicates that EDI drought indexes had the smallest value in 1991. Average value of the
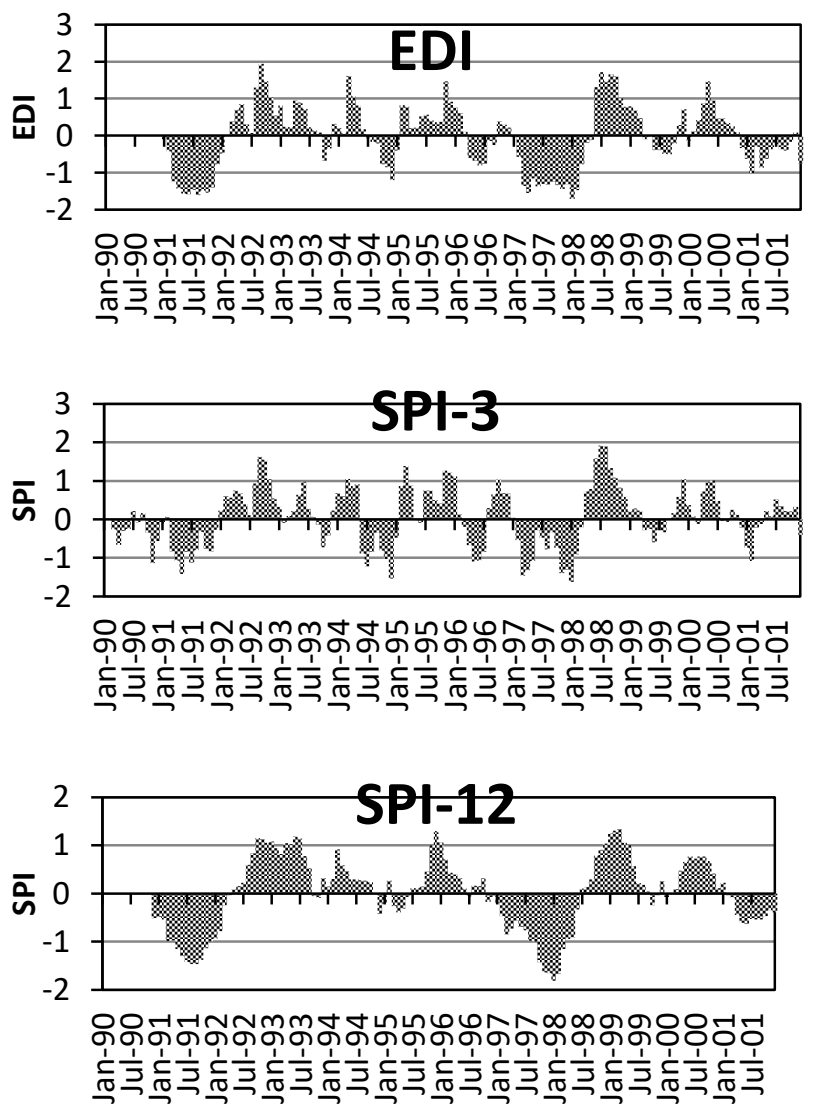

Figure 5.Historical drought indexes in Wonogiri District .
EDI index is above -2 so that the drought in this year classified as severe drought. This severe drought happened for a year. Besides 1991, 1997 show the small value of the EDI index too. The onset of the severe drought is in early 1997, with the peak of the severity was in the early year of 1998 .

SPI drought index shows the difference result from the EDI drought index. The smallest value of the drought values based on SPI drought index is 1997 for all of the time series. The lowest index is above -2 so that the drought in Wonogiri District based on SPI drought indexes classified into drought severe.

SPI-1, -3, -6, -12, and -24 indexes have the different characterization among those indexes. SPI-1 index is very sensitive due to precipitation. As shown in Figure 6. The SPI indexes becomes small when the amount of the precipitation is low and become high when the precipitation amount is high. Besides, the extremes value do not happen in dry periods but in wet periods. The condition occurs because the SPI-1 compares monthly rainfall data among the same month data for different years. In other words, SPI-1 has relativity through the same month. Accordingly, The SPI-1 could not define the drought status accurately.
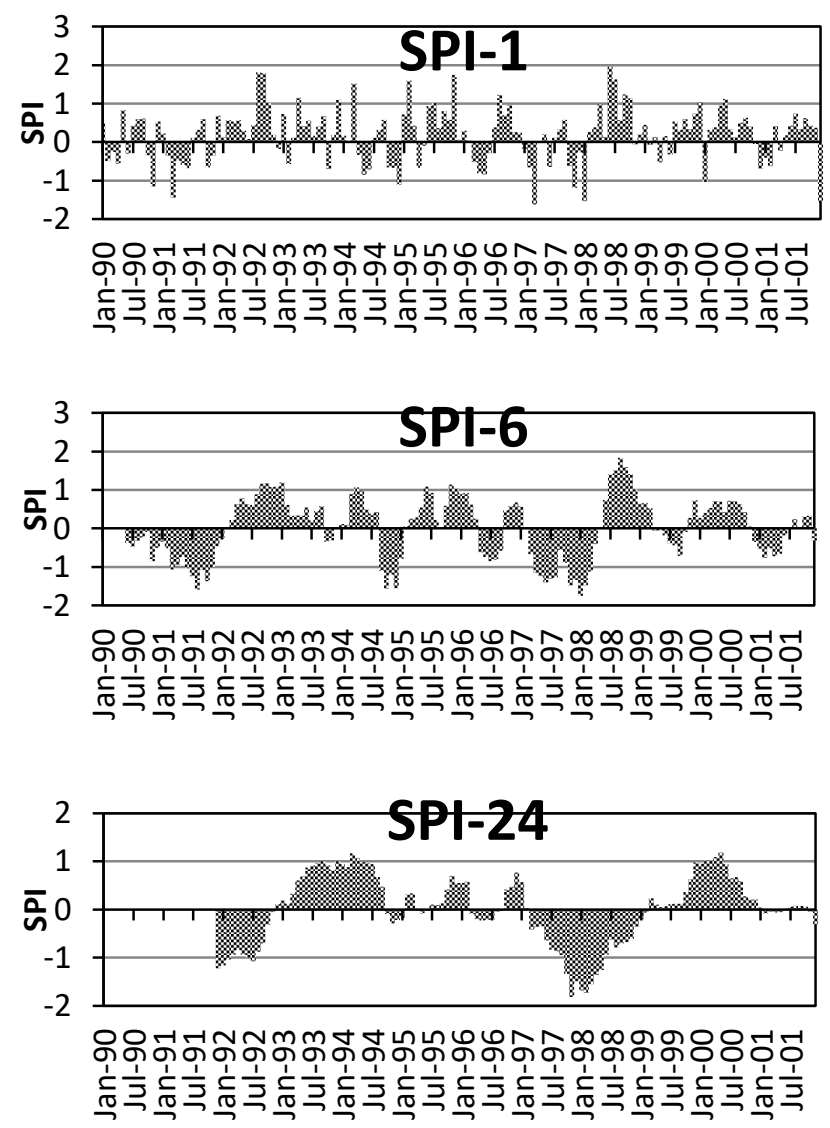

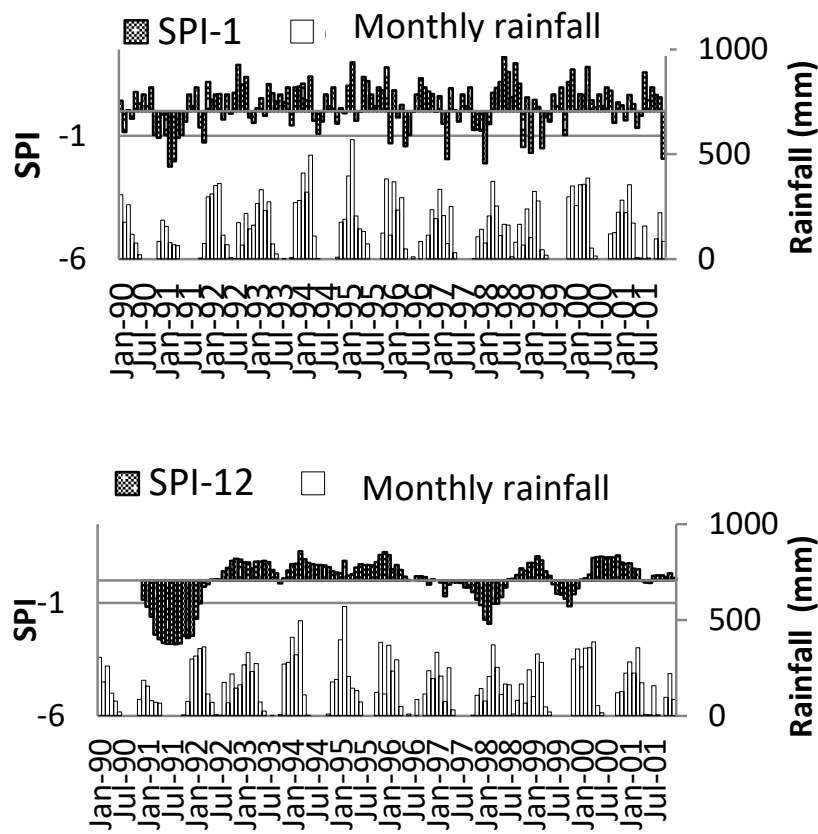

Figure 6.The comparisons between SPI-1 and SPI-12 in Selogiri rain gauge station (Karlina, 2013).
SPI drought indexes that could define actual drought condition accurately is SPI-12. This SPI has the same characteristic as EDI drought index. Both of these methods give the same value, so that agrees with the precipitation data. In order to see the spatial distribution of the drought, the mapping of the drought condition was done for the extreme condition, in 1997. The Wonogiri District drought map is shown in Figure 7. Areas with the lowest drought classification are Girimarto, Jatipuro, Jatisrono, Jatiroto, Slogohimo, Bulukerto, Purwantoro, and Kismantoro. Those areas tend to have higher precipitation than the other areas.

\subsection{Future Drought}

Future drought assessment using EDI and SPI methods for A2 and B2 scenarios give the different characteristic. Due to A2 scenario, drought intensity in the future condition is less than the historical condition. 2080's period is dominated by wet season. Future drought map is shown in Figure 8.

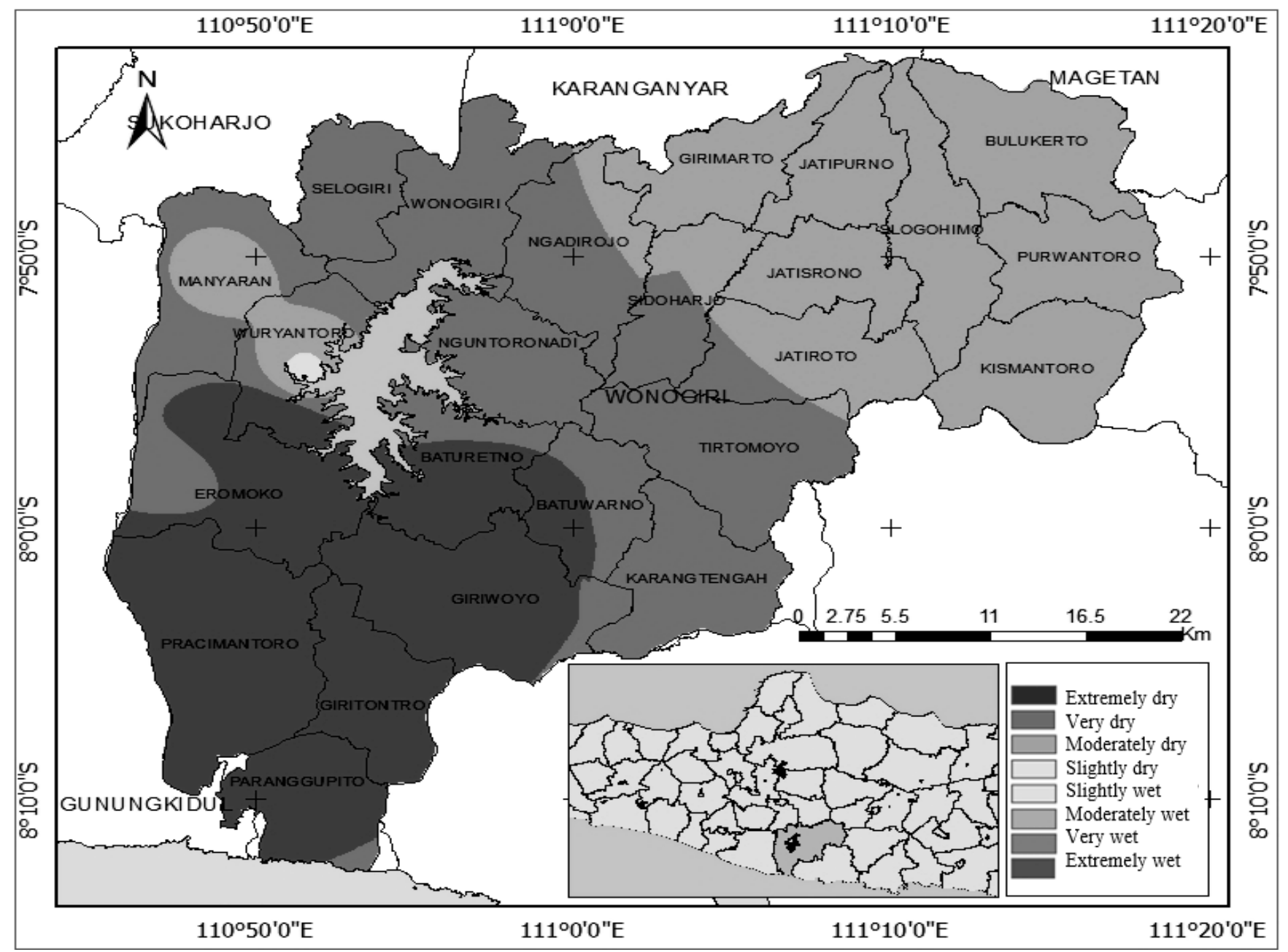

Figure 7.Wonogiri District drought map in 1997 based on EDI. 

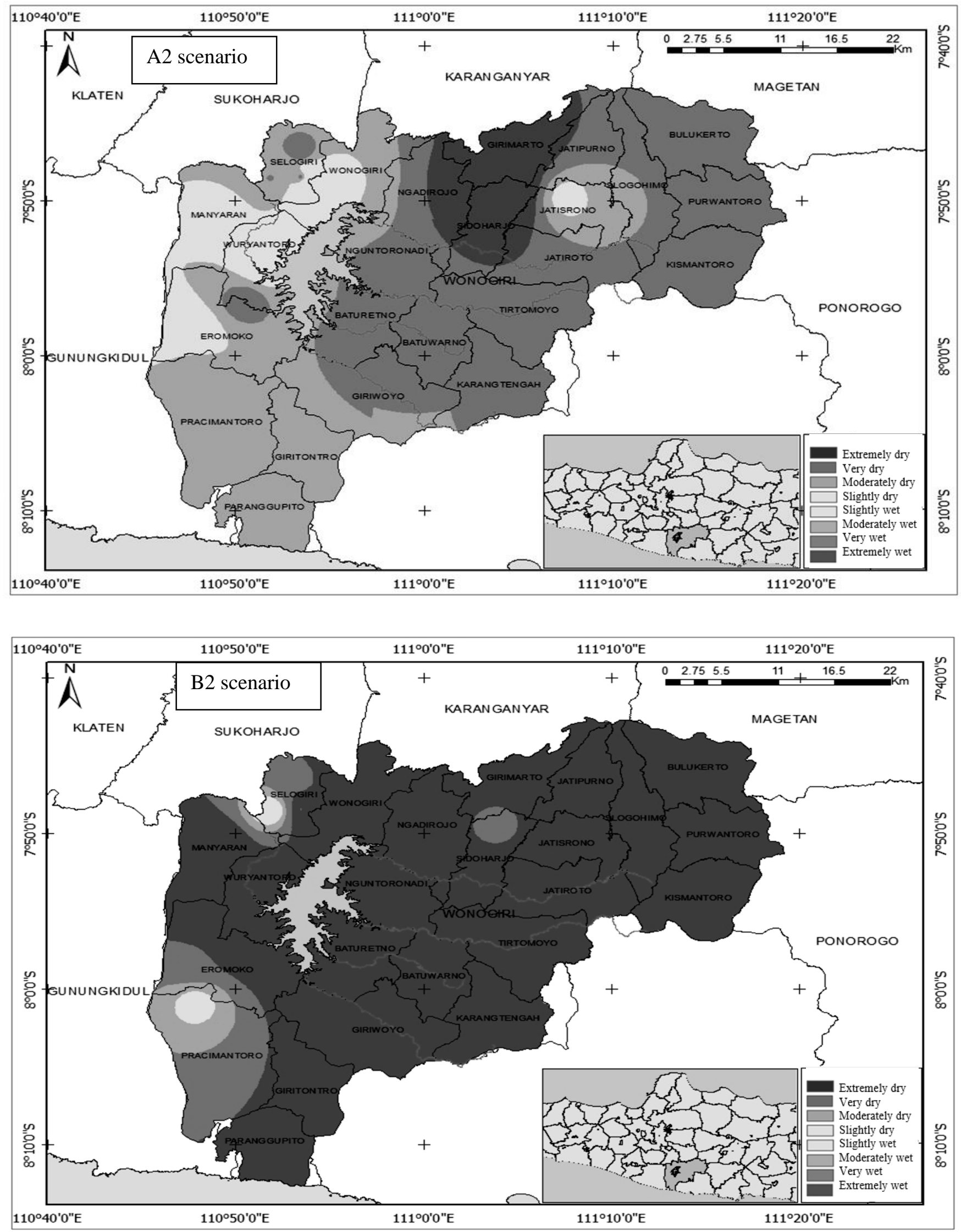

Figure 8.Drought maps in Wonogiri District for 2050's period based on EDI method. 
B2 scenarios give the different result from A2 scenarios. The B2 scenarios result show that the drought condition in the future condition has the same characteristic as the historical condition. If it's compared with A2 scenarios, B2 scenarios are drier than A2 scenarios. This happens because A2 scenarios give higher extremes condition than $\mathrm{B} 2$ scenarios. Although the drought condition based on A2 is less severe than $\mathrm{B} 2$, the dry period is longer than B2.

\section{CONCLUSIONS AND RECOMMENDATIONS}

\subsection{Conclusions}

The conclusions that came from the result of this research are as follows:

a) Drought indexes that could define the actual meteorological drought condition are EDI and SPI12.

b) The most severe historical drought happened in 1997 with the peak of the drought occurred in the early year of 1998 for both methods, EDI and SPI.

c) Based on A2 scenarios, future drought condition is less severe than historical drought; different with B2 scenarios that give future drought condition is almost the same as historical drought condition.

d) The areas that have a high vulnerability to drought for the historical condition are Eromoko, Baturetno, Giriwoyo, Pracimantoro, Giritontro, and Paranggupito.

e) The areas that have a high vulnerability to drought for the future condition are Girimarto, Jatipurno, Jatisrono, Jatiroto, Slogohimo, Bulukerto, Purwantoro, and Kismantoro.

\subsection{Recommendations}

The followings are several suggestions for the development of next research: a) Meteorological drought condition is needed to check with other drought assessment using another drought assessment method, such as a hydrological method.

b) Future precipitation prediction is needed to check with another method, with higher resolution so that could predict future prediction properly.

\section{REFERENCES}

Byun, H. R. \& Wilhite, D. A., 1999. Objective Quantification of Drought Severity and Duration. American Meteorological Society, Issue 12, pp. 27472756.

Heddinghaus, T. R. \& Sabol, P., 1991. A Review of the Palmer Drought Severity Index and Where Do We Go from Here?

Hessami, M., Gachon, P., Ouarda, T. B. \& St-Hilaire, A., 2007. Automated Statistical Downscaling.

IPCC, 2000. IPCC Special Report: Emissions Scenarios.

Karlina, 2013. Drought Analysis Using EDI and SPI Method to Mitigate Drought Disaster in Wonogiri District. Yogyakarta, The 4th International Seminar of HATHI.

Lloyd-Hughes, B. \& Saunders, M. A., 2002. A Drought Climatology for Europe. Issue 22, pp. 15711592.

McKee, T. B., Doesken, N. J. \& Kleist, J., 1993. The Relationship of Drought Frequency and Duratin to Time Scales, Anaheim California. 
[this page intentionally left blank] 